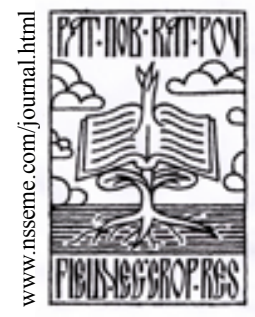

\title{
Effect of Genotype and Applied Management on Alfalfa Yield and Quality
}

\author{
Dragan Milić • Slobodan Katić • Snežana Katanski • \\ Goran Dugalić • Nikola Bokan • Sanja Vasiljević
}

\author{
received: 24 February 2014, accepted: 25 July 2014 \\ published online: 15 September 2014 \\ (c) 2014 IFVC \\ doi: $10.5937 /$ ratpov $51-5571$
}

\begin{abstract}
Summary: It is essential to apply advanced management for successful production of alfalfa hay with premium quality (high content of protein and minerals). The maximum yield and the best quality of alfalfa in Serbia can be obtained by cutting four or five times per year. In alfalfa stands, use of cutting system with three cuts per year is inefficient and does not allow full exploitation of cultivar genetic potential and environmental conditions. It is possible, and economically beneficial to grow alfalfa on pseudoglay soils after application of lime and organic manure, with recommended rates $2.5 \mathrm{t} \mathrm{ha}^{-1}$ lime and $30 \mathrm{t} \mathrm{ha}^{-1}$ manure. Cutting alfalfa at the beginning of flowering stage ( 5 cuts per year) provides hay with better quality - higher content of crude protein and lower portion of fibre fractions (neutral detergent fibre, acid detergent fibre, acid detergent lignin), and there is no reduction in dry matter yield. There is no differences in alfalfa quality after application of lower $\left(2.5 \mathrm{t} \mathrm{ha}^{-1}\right)$ and higher dose $\left(5.0 \mathrm{t} \mathrm{ha}^{-1}\right)$ of lime $+30 \mathrm{tha}^{-1}$ of organic manure, but there is significant increase of dry matter yield and protein yield per hectare followed by higher level of metabolic energy per unit area. Upon the results of this study, base of successful alfalfa production would be to develop management system and cultivars for different environments that would maximize hay yields without significant loses of quality.
\end{abstract}

Keywords: alfalfa, crop yield, cultivars, cuttings, fertilization, genotyping, quality

\section{Introduction}

Alfalfa is an ancient crop well adapted to various agro-ecological conditions. It is grown all over the world, and estimates from late 1980s reported on sown areas of over 30 million hectares (Michaud et al. 1988), while in Serbia alfalfa is the most important forage crop with growing area of about 200,000 hectares and average hay yield of $5.7 \mathrm{t} \mathrm{ha}^{-1}$ (SYS 2011). However, use of certified seeds of selected cultivars, fertilization, irrigation, weed control, pest, disease, proper use and relevant cutting intensity can result in hay yield of 16-20 $\mathrm{tha}^{-1}$ in period of 4-5 years (Katić et al. 2013a). It is essential to apply advanced growing management for successful production of alfalfa hay with premium quality (high content of protein and minerals). In addition, providing sufficient amounts of nutrients by fertilization is a

D. Milić $\bullet$ S. Katić •S. Katanski •S. Vasiljević

Institute of Field and Vegetable Crops, 30 Maksima Gorkog, 21000 Novi Sad, Serbia

e-mail: dragan.milic@ifvcns.ns.ac.rs

G. Dugalić • N. Bokan

University of Kragujevac, Faculty of Agronomy, 34 Cara Dušana, 32000 Čačak, Serbia very important factor in profitable alfalfa production (Lanyon \& Griffith 1988).

The maximum yield and the best quality of alfalfa in Serbia can be obtained by cutting four or five times per year (Katić et al. 2007). Harvesting alfalfa at earlier development stages (early flower $-10 \%$ blooms in stand), produces alfalfa hay with improved quality, i.e. more crude protein and less crude cellulose (Lloveras et al. 1998, Katic et al. 2003). Harvest timing is the most powerful tool under the alfalfa grower's control to affect yield and quality and ultimately increase profitability potential; more so than the cultivar choice, fertilization and other management factors (Orloff \& Putnam 2006). Cutting frequency, or more accurately the maturity of the alfalfa at the time of harvest, determines forage quality and yield (Orloff \& Putnam 2010). Yield and quality of alfalfa hay are significantly influenced by the choice of cultivar. In addition, it is of great importance for each cultivar to choose optimal cutting schedule

\section{Acknowledgements:}

This research was funded by the Serbian Ministry of Education, Science and Technological Development within the project BT 31024. 
(Katić et al. 2007). In order to achieve balanced production of fodder for livestock throughout the year, it is necessary to use varieties that differ in time of earliness (Kallenbach et al. 2002). In the USA, planting alfalfa cultivars with different dormancy classes can improve alfalfa hay quality because non-dormant cultivars should be cut in earlier stages and level of hay quality decreased more slowly with advanced plant maturity (Orloff \& Putnam 2004). Besides differences in fall growth and winter survival, varieties with less dormancy will tend to re-grow faster after cutting than more dormant varieties (Frate et al. 2012).

There are quality differences among cultivars of alfalfa, but they are rarely quantified in trials because laboratory analyses are costly and because quality parameters are so closely related to maturity (Sheaffer et al. 1998, Katić et al. 2009b, Frate et al. 2012). Genetic variation in forage quality components (CP, NDF, ADF and ADL) in alfalfa is present (Sheaffer et al. 1998, Katić et al. 2009b), also a seasonal variation of forage quality is significant and under the influence of higher air temperatures and lower soil moisture. Contribution to the seasonal variation at least partially is a result of the faster growth and maturity of alfalfa plants in summer (Katić et al. 2009b). Many researches have confirmed reduces of alfalfa forage quality when plants were cut in late maturity stages (Sheaffer et al. 1998, Sheaffer et al. 2000, Tabacco et al. 2002, Schwab et al. 2005, Katić et al. 2005). Unfortunately, actuality of alfalfa production is that yield and quality are inversely related. As yield grows, nutritive value usually decreases and vice versa. Cutting alfalfa at early maturity growth stages (i.e. pre-bud or early-bud) makes level of forage quality high, but yield decreases. Conversely, alfalfa cut in the bloom stage or green pods is higher yielding but forage quality is lower (Orloff \& Putnam 2006).

Because of these facts, fundament of successful alfalfa production would be to develop management system and genotype choice that would maximize hay yields without significant loses of quality (Lamb et al. 2003).

In alfalfa production, it is essential to have agro-ecological conditions in mind, mostly soil characteristics (Katić et al. 2013a), because alfalfa is a plant indicator of soil acidity (Hauptvogel 2003).

Soil acidity and process of soil acidification represent global issue that limits plant production all around the world. Estimations are that about 30\% of soil worldwide and more than $50 \%$ of the world's potentially arable lands are acidic, or unfavourable for agriculture production (Von Uexkull \& Mutert 1995).

Acid soils are characterized by high levels of $\mathrm{Al}^{3+}$ and $\mathrm{Mn}^{2+}$ ions, and they have deficit in $\mathrm{Ca}, \mathrm{Mg}, \mathrm{P}$ and other nutrients (Dall's et al. 1996). Soil acidity traditionally can be solved with lime application and subsequently elimination of $\mathrm{Al}$ toxicity in the plough layer, but not in the subsoil (Grewal \& Williams 2003, Reyno et al. 2013).

The growing area of alfalfa is limited due to its sensitivity to soil acidity and $\mathrm{Al}$ toxicity (Khu et al. 2012), and for planting of this species the most favourable soils are those with neutral to slightly alkaline reactions with $\mathrm{pH}$ level from 6.6 up to 7.5 (Lanyon \& Griffith 1988). According to Grewal \& Williams (2003) and Dugalić et al. (2011), higher level of acidity in soils and the concentration of $\mathrm{Al}^{3+}$ ions prevent the development of alfalfa roots and reduce symbiotic nitrogen fixation. Alfalfa biomass yields and the ability to survive are questionable because of inhibited root growth in soils with low $\mathrm{pH}$ (Khu et al. 2012). In Serbia, it is of great importance to broaden growing area of alfalfa on light or medium acid soils because it coincides with main livestock production regions (Katić et al. 2009a).

Alfalfa breeding focused on conventional methods has not succeeded in improving tolerance on genetic base to soil acidity, or such results are very modest. The lack of Altolerant alfalfa cultivars can be attributed to multiple factors including the absence of robust protocols for evaluating and selecting plant response to $\mathrm{Al}$ (Khu et al. 2012). Progress can be achieved using modern biotechnology methods (tissue culture) combining with molecular DNA markers in breeding procedures (Bouton 1996, Reyno et al. 2013). Breeding efforts in Serbia related to interspecies hybridization between $M$. sativa ssp. sativa and M. sativa ssp. falcata gene pools contributed to creation of germplasm/ cultivars more tolerant to soil acidity, but still including lime as ameliorative treatment before planting (Katić et al. 2009b, Katić et al. 2013b). Lime application has been the only powerful method for growing alfalfa on acid soils (Gomes et al. 2002, Grewal \& Williams 2003, Katić et al. 2009b), but lime rates can vary upon differences in $\mathrm{pH}$ level and soil characteristics (Gomes et al. 2002, Dugalić et al. 2009; Katić et al. 2013b). Grewal \& Williams (2003) suggest that liming on acid soils not only increases yield but also leads to improvement of alfalfa forage quality (leaf to stem ratio, crude protein and $\mathrm{Ca}$ content). 
Main goal of this paper was to assess the alfalfa improvement efforts in breeding and selection strategy, applied alfalfa management (cutting schedule and fertilization rates of $\mathrm{Ca}$ and organic manure), and their influence on yield and quality in different environments.

\section{Materials and Methods}

Field experiments were carried out in two sites in Serbia located at: (1) Čenej near Novi Sad, and (2) Drakčići near Kraljevo, during2010-2011, in order to compare genetic potential between the new created cultivars (Banat VS, Nijagara, NS Alfa) and one commercial as control cultivar (NS Mediana ZMS $\mathrm{V})$. Cultivars were tested in different management systems (cutting schedules, fertilization treatments) and different environments. The sites were characterized by contrasting soil conditions (Table 1).
Location 2 - Drakčicíi. Soil at Drakčići was pseudoglay with poor performance (high acidity and high mobile $\mathrm{Al}$ content); for the details see Dugalić et al. (2011). The experiment included four alfalfa cultivars planted in five treatments: 1 ) control (no lime or organic manure), 2) $2.5 \mathrm{tha}$ ${ }^{1}$ of lime, 3) $5.0 \mathrm{t} \mathrm{ha}^{-1}$ of lime, 4) $2.5 \mathrm{t} \mathrm{ha}^{-1}$ of lime + $30 \mathrm{t} \mathrm{ha}^{-1}$ of organic manure, 5) $5.0 \mathrm{t}$ ha 1 of lime + $30 \mathrm{tha}^{-1}$ of organic manure. Lime was applied with ploughing.

Green forage yield was measured in the field. Samples of about $200 \mathrm{~g}$, taken from the plots, were dried in a drying oven at $60^{\circ} \mathrm{C}$ for $72 \mathrm{~h}$ to determine dry matter content. Results were obtained from the second and third year of plant life (2010 and 2011) for dry matter yield, and from the second cut of the third year (2011) for forage quality testing. Samples for chemical analysis were cut at $5 \mathrm{~cm}$ height and sampled area was around $0.2 \mathrm{~m}^{2}$, amounting to $500 \mathrm{~g}$ of green

Table 1. Soil characteristics on locations Čenej and Drakčići (layer 0-30 cm)

\begin{tabular}{ccccccccc}
\hline Location & $\begin{array}{c}\text { Depth } \\
(\mathrm{cm})\end{array}$ & $\begin{array}{c}\mathrm{pH} \\
(\mathrm{KCl})\end{array}$ & $\begin{array}{c}\mathrm{CaCO}_{3} \\
(\%)\end{array}$ & $\begin{array}{c}\mathrm{N} \\
(\%)\end{array}$ & $\begin{array}{c}\text { Humus } \\
\text { content } \\
(\%)\end{array}$ & $\begin{array}{c}\mathrm{P}_{2} \mathrm{O}_{5} \\
(\mathrm{mg} / 100 \mathrm{~g})\end{array}$ & $\begin{array}{c}\mathrm{K}_{2} \mathrm{O} \\
(\mathrm{mg} / 100 \mathrm{~g})\end{array}$ & $\begin{array}{c}\mathrm{Mobile} \mathrm{Al} \\
(\mathrm{mg} / 100 \mathrm{~g})\end{array}$ \\
\hline Čenej & $0-30$ & 7.5 & 6.4 & 0.3 & 2.6 & 23.5 & 40.0 & - \\
Drakčići & $0-30$ & 4.8 & - & 0.2 & 2.5 & 2.7 & 12.6 & 16.2 \\
\hline
\end{tabular}

The randomized complete block design trials with three replications were set up in the spring 2009, with a seeding rate of $15 \mathrm{~kg} \mathrm{ha}^{-1}$. The elementary plot was $5 \mathrm{~m}^{2}(5 \times 1 \mathrm{~m})$ with the spacing between rows, plots and blocks of $20 \mathrm{~cm}, 40 \mathrm{~cm}$ and $1 \mathrm{~m}$, respectively. The effects of different management systems on five trait parameters, including dry matter yield $\left(\mathrm{t} h \mathrm{~h}^{-1}\right)$, crude protein $(\mathrm{CP})$, neutral detergent fibre (NDF), acid detergent fibre (ADF), and acid detergent lignin (ADL) contents $\left(\mathrm{g} \mathrm{kg}^{-1}\right)$, were analysed on both locations.

Location 1 - Čenej. The soil was low carbonate chernozem with good physical properties, neutral $\mathrm{pH}$ reaction and rich in nutrients. The experimental treatments included three cutting schedules at different maturity stages, according to Kalu and Fick (1981): a - early flowering stage (early cutting 5 cuts), b - late flowering stage (medium cutting, 4 cuts), and c - late cutting (green-pod stage, 3 cuts), because famers in Serbia mostly use these 3 cutting schedules. forage. Particular attention was paid to ensure that the samples were homogenized and ground to a particle size of $\varnothing=0.8 \mathrm{~mm}$. The analyses were carried out using standard methods, namely the Filter Bag Technique for neutral detergent fibre (NDF), acid detergent fibre (ADF), and acid detergent lignin (ADL). The analyses were performed on the Ankom 2000 Fiber Analyzer (Ankom Technology Corp., NY, USA). The crude protein content was determined using the standard chemical analysis proposed by Kjeldahl.

Dry matter yield data were analysed by the three-way analysis of variance for trials: factor A cutting system (Čenej) and lime treatment (Drakčići), factor B cultivar, and factor $\mathrm{C}$ year. The two-factorial analysis of variance was used for chemical analysis. At Cenej, cultivar was factor A and cutting schedule was factor $\mathrm{B}$, while at the second location, lime treatment was factor $A$ and cultivar was factor B.

The LSD test was used to test the significance of differences. 


\section{Results and Discussion}

Obtained results clearly show differences in dry matter yield between cultivars and cutting management (Table 2).

In the second year of stand life (2010), the highest yields of dry matter were recorded in beginning of flowering stage $\left(20.7 \mathrm{t} \mathrm{ha}^{-1}\right)$, while in 2011 there were no significant differences in dry matter yield between stages of beginning of flowering $\left(24.3 \mathrm{t} \mathrm{ha}^{-1}\right)$ and full flowering $(24.6 \mathrm{t}$ $\left.\mathrm{ha}^{-1}\right)$, probably because of the climate conditions in that period. In both following years (2010 and 2011), the lowest yields were obtained in green pod stage -3 cuts per year, 17. $9 \mathrm{t} \mathrm{ha}^{-1}$ and 18.5 t ha-1 (Table 1). Overall data showed that the highest dry matter yields were obtained with cultivars Nijagara (21.7 $\mathrm{t} \mathrm{ha}^{-1}$ ) and NS Alfa $\left(21.3 \mathrm{t} \mathrm{ha}^{-1}\right)$, and the lowest yield was observed with cultivar Banat VS $\left(20.3 \mathrm{tha}^{-1}\right)$. During the examined period cultivar $x$ cutting schedule interaction demonstrated that the highest yield performance was accomplished with cultivars Nijagara and NS Mediana ZMS V when they were cut in medium cutting systems, though in the stages of full flowering, in the less intensive cutting system ( 3 cuts).

Our results confirmed previous results (Lloveras et al. 1998, Tabacco et al. 2002, Lamb et al. 2003, Katić et al. 2007) regarding significant influence of cutting schedule on alfalfa dry matter yields. The compromise between yield, forage quality, and stand persistence is a challenging problem. According to Sheaffer et al. (2000), Kallenbach et al. (2002) and Katić et al. (2007), alfalfa should be cut in the beginning of flowering stage in order to achieve maximum yield and quality, as it was confirmed in our results. However, Orloff \& Putnam (2004) indicated that it is not possible to cut alfalfa stand in all fields in the optimal phase and five times per year, so an alternative use of four and five cuttings per year, for the conditions of Serbia, could be the most appropriate solution. The best overall approach to cutting management is likely a mixed strategy, not purely cutting for yield nor solely for quality (Orloff \& Putnam 2010). Forage quality analyses at Čenej location clearly demonstrated the importance of cutting schedule on dry matter quality in alfalfa. In addition, there was no difference between alfalfa cultivars when comparing mean values of the examined traits (Table 3 ).

There is a significant difference between cutting schedules for all evaluated quality traits. The highest values of CP content were recorded at the beginning of flowering stage $\left(218.2 \mathrm{~g} \mathrm{~kg}^{-1}\right)$, as well as lowest values of NDF $\left(362.6 \mathrm{~g} \mathrm{~kg}^{-1}\right)$, ADF $\left(311.6 \mathrm{~g} \mathrm{~kg}^{-1}\right)$ and $\operatorname{ADL}\left(68.4 \mathrm{~g} \mathrm{~kg}^{-1}\right)$ content. Distinctions in cultivar $\times$ cutting schedule interaction clearly demonstrated advantage of early cutting system for all cultivars. Late cutting system with 3 cuts per year (stage of green pod) did not allow full exploitation of genetic potential for yield and quality traits in all examined cultivars. The results of the present study suggest the absence of significant genetic variation in the crude protein content of alfalfa in mean values (Table 3). Highest CP contents and hence better forage quality were found in the cultivars Nijagara $\left(239.1 \mathrm{~g} \mathrm{~kg}^{-1}\right)$ and NS Alfa $\left(224.7 \mathrm{~g} \mathrm{~kg}^{-1}\right)$ at the beginning of flowering stage. Today, NDF and ADF content are more often used as the indicator of fibre quality parameters because of its greater

Table 2. Dry matter yield of alfalfa cultivars $\left(t \mathrm{tha}^{-1}\right)$ during 2010 - 2011 with different cutting schedules at Čenej location

\begin{tabular}{|c|c|c|c|c|c|c|}
\hline \multirow[t]{2}{*}{ Year } & \multirow[t]{2}{*}{ Cutting schedule } & \multicolumn{5}{|c|}{ Cultivar } \\
\hline & & Banat VS & Nijagara & NS Alfa & NS Mediana ZMS V & Average \\
\hline \multirow{3}{*}{2010} & Early ( 5 cuts) & 19.4 & 21.5 & 21.7 & 20.3 & 20.7 \\
\hline & Medium ( 4 cuts) & 18.5 & 20.6 & 19.7 & 20.4 & 19.8 \\
\hline & Late ( 3 cuts) & 18.3 & 18.7 & 18.1 & 16.4 & 17.9 \\
\hline \multirow[t]{4}{*}{2011} & Early ( 5 cuts) & 24.0 & 24.4 & 24.7 & 24.0 & 24.3 \\
\hline & Medium ( 4 cuts) & 24.1 & 24.5 & 24.5 & 25.3 & 24.6 \\
\hline & Late ( 3 cuts) & 17.4 & 20.4 & 19.1 & 17.0 & 18.5 \\
\hline & Average & 20.3 & 21.7 & 21.3 & 20.6 & 21.0 \\
\hline LSD & Cutting schedule & & Cultivar & & System $\mathrm{x}$ cultivar & $S_{x} C_{x} Y$ \\
\hline 0.05 & 0.4 & & 0.5 & & 0.8 & 2.0 \\
\hline 0.01 & 0.5 & & 0.6 & & 1.1 & 2.6 \\
\hline
\end{tabular}


Table 3. Content of crude protein (CP), neutral detergent fibre (NDF), acid detergent fibre (ADF) and acid detergent lignin (ADF) in $\mathrm{g} \mathrm{kg}^{-1}$ of alfalfa cultivars in different cutting management in second cut of 2011 at Čenej location

\begin{tabular}{|c|c|c|c|c|c|}
\hline Cultivar & Cutting system & $\mathrm{CP}$ & NDF & $\mathrm{ADF}$ & $\mathrm{ADL}$ \\
\hline \multirow{3}{*}{ Banat VS } & Early ( 5 cuts) & 211.3 & 362.3 & 312.0 & 67.2 \\
\hline & Medium ( 4 cuts) & 175.4 & 462.3 & 374.8 & 91.2 \\
\hline & Late ( 3 cuts) & 140.8 & 549.4 & 454.7 & 118.0 \\
\hline \multirow{5}{*}{ Nijagara } & Average & 175.8 & 458.0 & 380.5 & 92.2 \\
\hline & Early ( 5 cuts) & 239.1 & 372.9 & 310.1 & 69.7 \\
\hline & Medium ( 4 cuts) & 167.8 & 489.0 & 386.3 & 90.6 \\
\hline & Late ( 3 cuts) & 153.4 & 532.2 & 408.1 & 104.5 \\
\hline & Average & 186.7 & 464.7 & 368.2 & 88.3 \\
\hline \multirow{3}{*}{ NS Alfa } & Early ( 5 cuts $)$ & 224.7 & 327.2 & 287.6 & 60.5 \\
\hline & Medium ( 4 cuts) & 166.6 & 450.4 & 362.6 & 87.0 \\
\hline & Late ( 3 cuts) & 161.1 & 519.6 & 417.5 & 108.9 \\
\hline \multirow{6}{*}{ NS Mediana ZMS V } & Average & 184.1 & 432.4 & 355.9 & 85.4 \\
\hline & Early ( 5 cuts) & 197.7 & 387.8 & 336.8 & 76.3 \\
\hline & Medium ( 4 cuts) & 190.0 & 405.6 & 339.6 & 77.0 \\
\hline & Late ( 3 cuts) & 170.9 & 519.0 & 403.3 & 105.5 \\
\hline & Average & $\underline{186.2}$ & $\underline{437.5}$ & $\underline{359.9}$ & $\underline{86.3}$ \\
\hline & $\begin{array}{l}\text { System x cult } \\
0.05 \\
\text { LSD }\end{array}$ & 28.4 & 67.9 & 64.8 & 15.5 \\
\hline \multicolumn{2}{|c|}{ Average cutting schedule } & $\mathrm{CP}$ & NDF & $\mathrm{ADF}$ & $\mathrm{ADL}$ \\
\hline \multicolumn{2}{|c|}{ Early ( 5 cuts) } & 218.2 & 362.6 & 311.6 & 68.4 \\
\hline \multicolumn{2}{|c|}{ Medium ( 4 cuts) } & 175.0 & 451.8 & 365.8 & 86.5 \\
\hline \multicolumn{2}{|c|}{ Late ( 3 cuts) } & 156.5 & 530.1 & 420.9 & 109.2 \\
\hline \multicolumn{2}{|c|}{$\begin{array}{c}\text { LSD Cutting schedule } 0.05 \\
0.01\end{array}$} & $\begin{array}{l}14.2 \\
19.2\end{array}$ & $\begin{array}{l}32.4 \\
44.0\end{array}$ & $\begin{array}{l}34.0 \\
46.1\end{array}$ & $\begin{array}{c}7.8 \\
10.5\end{array}$ \\
\hline LSD Cultivar & & $\begin{array}{l}16.4 \\
22.2\end{array}$ & $\begin{array}{l}37.4 \\
50.8\end{array}$ & $\begin{array}{l}39.2 \\
53.2\end{array}$ & $\begin{array}{c}9.0 \\
12.2\end{array}$ \\
\hline
\end{tabular}

accuracy (Katić et al. 2009b). In our study, the cultivars Banat VS and NS Alfa had the lowest NDF, ADF and ADL content (Table 3.) in early cutting system, meaning that this cultivar's hay had best quality and would be preferred to grow in the most intensive cutting regimes (5-6 cuts).

Obtained results clearly demonstrated that cutting alfalfa in the beginning of flowering stage ( 5 cuts per year) allowed production of hay with better quality higher content of $\mathrm{CP}$, and lower content of NDF, $\mathrm{ADF}$ and $\mathrm{ADL}$, without significant reduction in dry matter yield.

The results of the study at the location Drakčići showed that the application of 2.5 and $5.0 \mathrm{tha}^{-1}$ of lime significantly increased the yields of dry matter (Table 4). 
Table 4. Dry matter yield of alfalfa cultivars $\left(t \mathrm{th}^{-1}\right)$ in 2010 and 2011 with different fertilizing treatments at Drakčići location

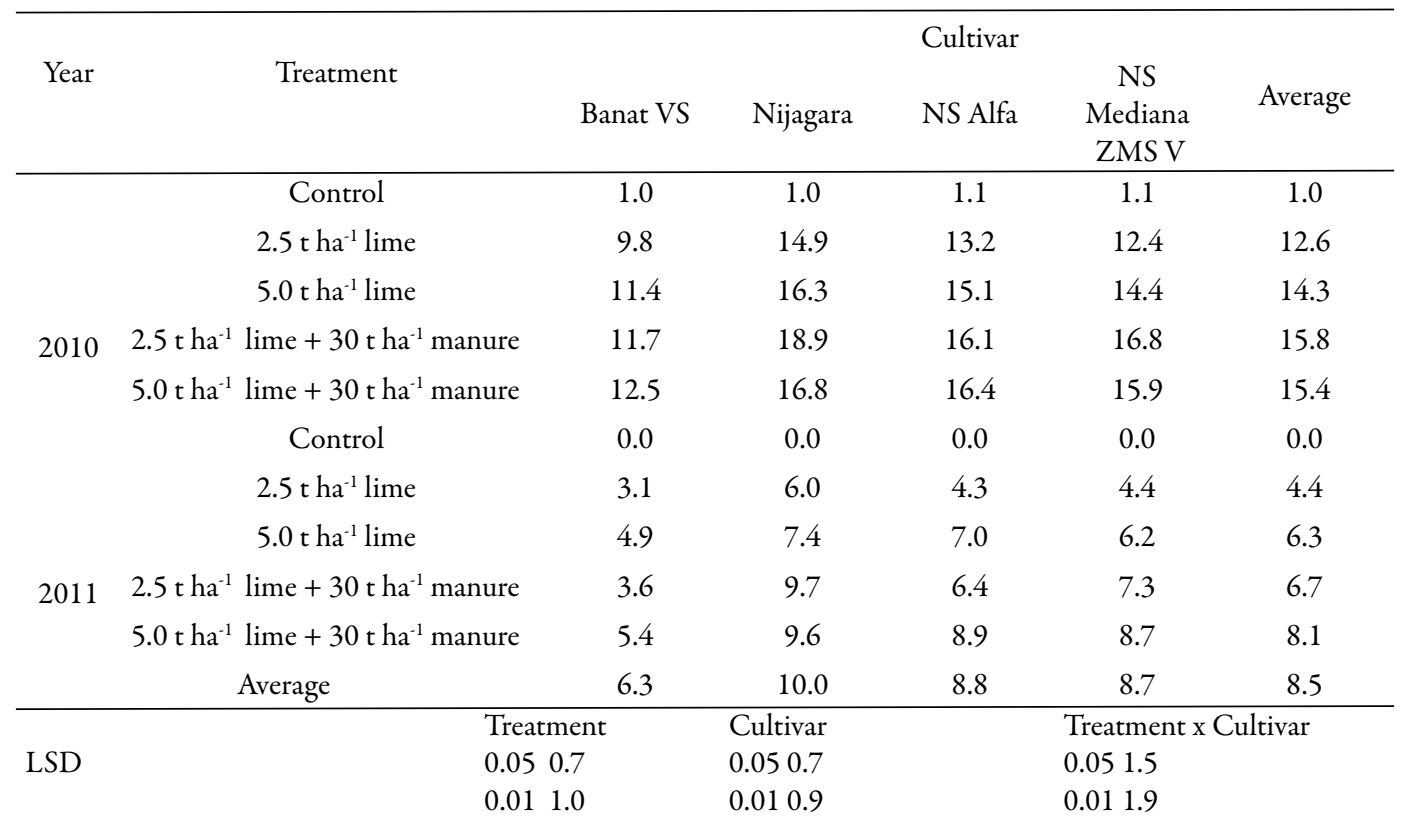

The yields of dry matter were significantly higher in the treatments in which liming and organic manure were applied in the second year of stand life (2010), and did not show significant differences between lower and higher dose of lime 2.5 and $5.0 \mathrm{t} \mathrm{ha}^{-1}$ respectively. During the third year of stand life treatment with higher lime rate outyielded the one with the lower dose by a significant margin $\left(6.7 \mathrm{t} \mathrm{ha}^{-1}\right.$ of hay compared to $\left.8.1 \mathrm{t} \mathrm{ha}^{-1}\right)$. Over the studied period (2010-2011), the highest yield was achieved with cultivar Nijagara $(10 \mathrm{t}$ $\mathrm{ha}^{-1}$ ) on cultivar mean basis, but also by cultivar $\mathrm{x}$ treatment interaction (Table 4). Explanation for this result is the existence of genetic tolerance for soil acidity, which is in line with previous studies (Gomes et al. 2002, Grewal \& Williams 2003). Namely, Nijagara was created using interspecies hybridization between M. sativa ssp. sativa and M. sativa ssp. falcata gene pools in order to create germplasm more tolerant to acid soils (Katić et al. 2009b, Katić et al. 2013b).

Analysis of forage quality in Drakčići on average mean basis showed differences between cultivar Banat VS and other following cultivars in quality traits (Table 5). Banat VS had higher CP content and lower content of NDF, ADF and ADL than other cultivars.

However, compared to dry matter yield results, Banat VS had the lowest ranking entry, the poorest yield performance. This can be explained by the fact that this cultivar represents Pannonian ecotype of alfalfa, which is intended for planting in soils reach in nutrients and neutral $\mathrm{pH}$ reaction (Katić et al. 2013b), inadequate for growing in the conditions observed at the Drakčići site. Additionally, this means that Banat VS was not able to grow and develop like Nijagara and NS Mediana ZMS V. These circumstances were the main reason why Banat VS was less mature when samples were taken, which likewise contributed to better quality performance of this cultivar, although Banat VS had modest yield expression.

There was no significance between treatments for the observed quality traits (data not shown), but there was a real linear constant difference in cultivar $\times$ treatment interaction (Table 5). Our results are in agreement with Grewal \& Williams (2003), who claim that liming improves not only yield performance of alfalfa, but also forage quality, i.e. nutritive value. This is also the case in our study, but we do not have results for the quality traits from the control treatment, because samples were taken in the third year of the trial when cultivars at the control treatment could not survive. Liming alfalfa with recommended rates $\left(2.5 \mathrm{tha}^{-1}\right)$ together with application of manure $\left(30 \mathrm{t} \mathrm{ha}^{-1}\right)$ significantly increased dry matter yield but also led to an increase of protein yield per hectare which was followed by 
Table 5. Content of crude protein (CP), neutral detergent fibre (NDF), acid detergent fibre (ADF) and acid detergent lignin (ADF) in $\mathrm{g} \mathrm{kg}^{-1}$ of alfalfa cultivars in different fertilizing treatments in second cut of 2011 at Drakčići location

\begin{tabular}{|c|c|c|c|c|c|}
\hline Cultivar & Treatment & $\mathrm{CP}$ & NDF & $\mathrm{ADF}$ & $\mathrm{ADL}$ \\
\hline \multirow{3}{*}{ Banat VS } & $2.5 \mathrm{t} \mathrm{ha}^{-1}$ lime & 188.8 & 377.8 & 292.5 & 77,1 \\
\hline & $5.0 \mathrm{t} \mathrm{ha}^{-1}$ lime & 180.6 & 401.8 & 314.3 & 79,1 \\
\hline & 2.5. tha ${ }^{-1}$ lime +30 t ha $^{-1}$ manure & 168.6 & 395.4 & 335.7 & 78,6 \\
\hline \multirow{7}{*}{ Nijagara } & $5.0 \mathrm{t} \mathrm{ha}^{-1}$ lime $+30 \mathrm{tha}^{-1}$ manure & 185.6 & 385.0 & 311.6 & 73,5 \\
\hline & Average & 180.9 & 390.0 & 313.5 & 77,1 \\
\hline & $2.5 \mathrm{t} \mathrm{ha}^{-1}$ lime & 181.4 & 398.3 & 311.0 & 78,7 \\
\hline & $5.0 \mathrm{t} \mathrm{ha}^{-1}$ lime & 174.1 & 414.4 & 329.9 & 85,3 \\
\hline & 2.5. $\mathrm{tha}^{-1}$ lime $+30 \mathrm{tha}^{-1}$ manure & 160.9 & 422.7 & 351.6 & 87,8 \\
\hline & $5.0 \mathrm{t} \mathrm{ha}^{-1}$ lime $+30 \mathrm{tha}^{-1}$ manure & 167.7 & 406.5 & 342.8 & 81,6 \\
\hline & Average & 171.0 & 410.5 & 333.8 & 83,4 \\
\hline \multirow{3}{*}{ NS Alfa } & 2.5 t ha $^{-1}$ lime & 168.7 & 419.3 & 324.3 & 86,7 \\
\hline & 5.0 t ha- ${ }^{-1}$ lime & 185.9 & 430.2 & 332.2 & 86,8 \\
\hline & 2.5. $\mathrm{t} \mathrm{ha}^{-1}$ lime $+30 \mathrm{tha^{-1 }}$ manure & 177.0 & 402.6 & 329.6 & 81,4 \\
\hline \multirow{7}{*}{ NS Mediana ZMS V } & $5.0 \mathrm{tha}^{-1}$ lime $+30 \mathrm{tha}^{-1}$ manure & 169.8 & 419.0 & 341.2 & 80,2 \\
\hline & Average & 175.3 & 417.8 & 331.8 & 83,8 \\
\hline & $2.5 \mathrm{t} \mathrm{ha}^{-1}$ lime & 178.2 & 389.1 & 307.6 & 76,7 \\
\hline & $5.0 \mathrm{tha}^{-1}$ lime & 162.9 & 424.8 & 345.0 & 87,1 \\
\hline & 2.5. tha ${ }^{-1}$ lime +30 t ha $^{-1}$ manure & 170.1 & 412.6 & 350.2 & 85,4 \\
\hline & $5.0 \mathrm{tha}^{-1}$ lime $+30 \mathrm{tha}^{-1}$ manure & 167.7 & 426.7 & 353.9 & 85,5 \\
\hline & Average & 169.7 & 413.3 & 339.2 & 83,7 \\
\hline \multirow{4}{*}{\multicolumn{2}{|c|}{$\begin{array}{r}\text { LSD Treatment } \mathrm{x} \text { cultivar } 0.05 \\
0.01\end{array}$}} & 8.4 & 22.0 & 17.4 & 5.1 \\
\hline & & 11.3 & 30.0 & 23.5 & 6.9 \\
\hline & & 16.8 & 44.0 & 34.8 & 10.2 \\
\hline & & 22.3 & 59.0 & 46.9 & 13.8 \\
\hline
\end{tabular}

higher level of metabolic energy (NEM and NEL) per unit area.

Nonetheless, data presented in this research at Drakčići location clearly demonstrated the possibility for growing alfalfa after application of lime and organic manure on pseudoglay soils. These results led to conclusion of presence of genetic variation on acid soils in alfalfa even in case when lime was applied and showed importance of management (cultivation practices) in border growing regions for alfalfa production.

In the upcoming years, alfalfa will continue to play a significant role in livestock production owing to its inherent characteristics, broad adaptation, positive impact on sustainable production systems and high protein yield per hectare (Reich 2012).

\section{Conclusions}

For successful alfalfa production in Serbia, it is essential to use well adapted commercial cultivars for different growing regions. Cultivar choice depends on ecological conditions (soil) and applied cultivation practices (cutting system, fertilization, and irrigation).

In alfalfa stands, use of cutting system with three cuts per year is inefficient and does not allow full exploitation of cultivar genetic potential and environmental conditions of Serbia. 
On pseudoglay soils, it is possible to grow alfalfa after application of lime and organic manure, with these recommended rates $-2.5 \mathrm{t} \mathrm{ha}^{-1}$ of lime and 30 tha ${ }^{-1}$ of manure.

Cutting alfalfa at the beginning of flowering stage ( 5 cuts per year) provides hay with better quality - higher content of $\mathrm{CP}$, and lower portion of fibre fractions (NDF, ADF, ADL) and there is no reduction in dry matter yield.

There was no differences in alfalfa quality after application of lower $\left(2.5 \mathrm{t} \mathrm{ha}^{-1}\right)$ and higher dose (5.0 $\left.t h^{-1}\right)$ of lime $+30 t$ ha $^{-1}$ of organic manure, but there is significant increase of dry matter yield and protein yield per.

Yield and quality of alfalfa highly depend on genetic factors (cultivar) and applied level of cultivation practices.

\section{References}

Bouton, J.H. (1996). Screening the alfalfa core collection for acid soil tolerance. Crop Sci. 36: 198-200.

Dall's, A., Buton, J.H., \& Parrott, W.A. (1996). Screening methods to develop alfalfa populations tolerant to acid aluminium toxic soils. Crop Sci. 36: 64-70.

Dugalić, G., Gajić, B., Katić, S. \& Stevović, V. (2008). Influence of liming on yield and chemical composition of alfalfa on acid soils. Cereal Research Communications 36(2): 995-998.

Dugalić, G., Bokan, N., Katić, S., \& Jelić, M (2011). Uticaj kreča i stajnjaka na promene agrohemijskih osobina pseudogleja. Agroznanje 12: 469-474.

Frate, E.C., Mueller, S.C., Orloff, S., \& Putnam, D. (2012). Variety selection - choosing the best for your field. Proceedings of the 2012 California Alfalfa \&Grain Symposium. 10-12 December, Sacramento, CA, USA.

Gomes, F.T., Borges, A.C., Neves, J.C.L., \& Fontes, P.C.R. (2002). Nodulation, nitrogen fixation and alfalfa dry matter production as affected by rates of limestone with different calcium: magnesium ratios applied. Cienc. Rural. [online]. 32(6): 925-930. Retrieved from http://alfalfa. ucdavis.edu/+symposium/2012f/index.aspx

Grewal, H.S. \& Williams, R. (2003). Liming and cultivars affect root growth, nodulation, leaf to stem ratio, herbage yield, and elemental composition of alfalfa on an acid soil. J. Plant Nutrition 26(8): 1683-1696.

Hauptvogel, P. (2003). Strategy of aspects of lucerne breeding to abiotic stress. Czech J. Genetics and Plant Breeding, 39: 163-167.

Kallenbach, L., Nelson, C.J. \& Coutts, J.H. (2002). Yield, quality, and persistence of grazing - and hay-type alfalfa under three harvest frequencies. Agron. J. 94: 1094- 1103.

Kalu, B.A., \& Fick, G.W. (1981). Quantifying morphological development of alfalfa for studies of herbage quality. Crop Sci. 21: 267-271.

Katic, S., Mihailovic, V., Karagic, Đ., Milic, D., \& Pataki I. (2003). Yield, morphology and chemical composition of five lucerne genotypes as affected by growth stage and the environment. Grassland Science in Europe 8: 376379.

Katic, S., Milic, D., Mihailovic, V., Mikic, A., \& Vasiljevic, S. (2005). Changes in crude protein content with advancing maturity in lucerne. XX International Grassland Congress: Offered papers. Dublin 26.06.-1.07.2005. pp. 270.
Katić, S., Mihailović, V., Milić, D., Karagić, Đ., \& Mikić, A. (2007). Uticaj učestalosti košenja na prinos i kvalitet krme NS sorti lucerke. Zbornik radova Instituta za ratarstvo i povrtarstvo 43(1): 239-244.

Katić S., Milić D., Lazarević B., Dugalić G.,\& Bokan N. (2009a). Stabilnost prinosa i dužina života lucerke na pseudogleju posle primene krečnjaka. Ratar. Povrt. 46(1): 81-88.

Katić, S., Milić, D., Karagić, Đ. Vasiljević, S., Glamočić, D., \& Jajić, I. (2009b). Variation of protein, cellulose and mineral content of lucerne as influenced by cultivar and cut. Biotechnology in Animal Husbandry 25(5-6): 1189-1188.

Katić, S., Milić, D., Karagić, Đ., Malidža, G., \& Katanski, S. (2013a). Ublažavanje negativnih efekata suše na prinos lucerke primenom agrotehničkih mera. Zbornik referata, 47 . Savetovanje agronoma Srbije, Zlatibor, Institut za ratarstvo i povrtarstvo, Novi Sad, 183-193.

Katić, S., Milić, D., Katanski, S., Vasiljević, S., Dugalić, G., \& Bokan, N. (2013b). Efekti đubrenja na prinos i ekonomičnost proizvodnje sena lucerke. Zbornik radova 18 . Savetovanja o biotehnologiji, Agronomski fakultet Čačak, 243-250.

Khu, D.M., Reyno, R., Brummer, E.C., \& Monteros, J.M. (2012). Screening methods for aluminium tolerance in alfalfa. Crop Sci. 52: 161-167.

Lamb, J.F.S., Sheaffer, C.C., \& Samac, D.A. (2003). Population density and harvest maturity effects on leaf and stem yield in alfalfa. Agron. J. 95: 635-641.

Lanyon, L.E., \& Griffith, W.K. (1988). Nutrition and fertilizer use. p. 333-372. In: A.A. Hanson et al. (eds.). Alfalfa and alfalfa improvement. Agron. Monogr. 29. ASA, Madison, WI.

Lloveras, J., Ferran, J., Alvarez, A., \& Torres, L. (1998). Harvest management effect on alfalfa (Medicago sativa $\mathrm{L}$.) production and quality in Mediterranean areas. Grass and Forage, Science, 53: 88-92.

Michaud, R., Lehnan, W.F., \& Rumbaugh, M.D. (1988). World distribution and historical development. Alfalfa and alfalfa improvement. Hanson, A.A., Madison, Wisconsin, USA, pp. 25-124.

Reich, J.M. (2012). Alfalfa's role in feeding a hungry world. Proceedings of the 2012 California Alfalfa \& Grain Symposium. 10-12 December, Sacramento, CA, USA. Retrieved from http://alfalfa.ucdavis.edu/+symposium/2012f/ index.aspx

Reyno, R., Khu, D.M., Monteros, M.J., Bouton, J.H., Parrot, W., \& Brummer, E.C. (2013). Evaluation of two transgenes for Aluminium tolerance in alfalfa. Crop Sci. 53: 15811588.

Statistical Yearbook of Serbia (2011). Retrieved from http:// www.media.srbija.gov.rs/medsrp/ dokumenti/SGS2011_ cyr.pdf

Tabacco, E., Borreani, G., Odoardi, M., \& Reyneri, A. (2002). Effect of cutting frequency on dry matter yield and quality of lucerne (Medicago sativa L.) in the Po Valley. Italian Journal of Agronomy 6: 27-33.

Orloff, S. \& Putnam, D. (2004). Balancing Yield, Quality and Persistence. Proceedings of National Alfalfa Symposium, 13-15 December, 2004, San Diego. Retrieved from http:// alfalfa.ucdavis.edu

Orloff, S. \& Putnam, D. (2006). Cutting schedule strategies to maximize returns. In: Proceedings, $36^{\text {th }}$ California Alfalfa and Forage Symposium, 11-13 December, Reno, CA, USA. pp. 229-245.

Orloff, S., \& Putnam, D. (2010). Adjusting alfalfa cutting schedules for economic conditions. Proceedings of the 2010 California Alfalfa \& Forage and Corn/Cereal Silage Mini-Symposium. November 30 - 2 December, Visalia, CA, USA. Retrieved from http://alfalfa.ucdavis. edu/+symposium/2010/ 
Schwab, P.M., Lamb, J.S.F., Sheaffer, C.C., \& Barnes D.K. (2005). Germplasm Variability and Environmental Effects on Stem Cellulose and Lignin Concentrations in Alfalfa. Journal of Agron. \& Crop Science 191: 386-392.

Sheaffer, C.C., Cash, D., Ehlke, N.J., Hansen, J.L., Henning J.C., Grimsbo, J. J., Johnson K.D., Peterson, M.A., Smith, M., \&
Viands, D.R. (1998). Entry x environment interactions for alfalfa forage quality. Agron. J. 90: 774-780.

Sheaffer, C.C., Martin, N.P., Lamb, J.F.S. Cuomo, G.R. Jewett, J.G., \& Quering. S.R. (2000). Leaf and stem properties of alfalfa entries. Agron. J. 92: 733-739.

Von Uexkull, H.P., \& Mutert, E. (1995). Global extent, development and economic impact of acid soils. Plant Soil. 171: $1-15$.

\title{
Prinos i kvalitet lucerke u zavisnosti od genotipa i tehnologije gajenja
}

\author{
Dragan Milić • Slobodan Katić • Snežana Katanski • \\ Goran Dugalić • Nikola Bokan • Sanja Vasiljević
}

Sažetak: Cilj rada je bio da se utvrdi uticaj genotipa i tehnologije gajenja na prinos i kvalitet lucerke. Postavljena su dva ogleda sa istim setom sorti (Banat VS, Nijagara, NS Alfa i NS Mediana ZMS V) na lokalitetima Rimski šančevi i Drakčići - rejon Kraljeva. Na lokalitetu Čenej ispitivan je uticaj sorte i sistema kosidbe na prinos i kvalitet lucerke, dok je u regionu Kraljeva ispitivan uticaj genotipa i različitih tretmana đubrenja krečom i stajnjakom. Dobijeni rezultati ukazuju da za uspešnu proizvodnju treba sejati sortno seme lucerke, a da izbor sorte zavisi od ekoloških uslova (zemljišta) i primenjene agrotehnike (režima kosidbe, đubrenja, navodnjavanja). Košenjem lucerke 3 puta godišnje ne iskorišćavaju se genetički potencijal sorte i agroekološki uslovi naše zemlje. Na pseudoglejnim zemljištima se može gajiti lucerka, posle primene krečnog materijala i stajnjaka. Rezultati ukazuju na značaj primene 2,5 t/ha kreča i 30 t/ha stajnjaka. Košenjem u fazi početka cvetanja ( 5 otkosa) dobija se bolji kvalitet - veći sadržaj sirovih proteina i manji udeo frakcija celuloze (NDF, ADF, $\mathrm{ADL})$, a ne dolazi do smanjenja prinosa suve materije lucerke. Kvalitet lucerke se ne razlikuje posle primene niže $(2,5 \mathrm{t} / \mathrm{ha})$ i više ( $5,0 \mathrm{t} / \mathrm{ha}$ ) doze krečnog materijala i $30 \mathrm{t} / \mathrm{ha}$ stajnjaka, ali dobija se povećanje prinosa suve materije, a time i veći prinos proteina i veća metabolička energija (NEM, NEL) po jedinici površine. Prinos i kvalitet suve materije lucerke najviše zavise od tehnologije gajenja (nivoa agrotehnike) i izbora sorte.

Ključne reči: đubrenje, genotip, kvalitet, lucerka, prinos, sistem kosidbe, sorte 